\title{
ПРО ДЕЯКІ СУЧАСНІ АСПЕКТИ УПРАВЛІННЯ КОМАНДОЮ ПРОЕКТУ
}

\section{ABOUT SOME MODERN ASPECTS OF PROJECT TEAM MANAGEMENT}

\author{
Передало Христина Станіславівна \\ кандидат економічних наук, доцент, \\ Національний університет «Львівська політехніка» \\ ORCID ID: https://orcid.org/0000-0003-3972-6178 \\ Огерчук Юрій Володимирович \\ кандидат економічних наук, доцент, \\ Національний університет «Львівська політехніка» \\ ORCID ID: https://orcid.org/0000-0003-1494-622X
}

\author{
Peredalo Khrystyna, Oherchuk Yurii \\ Lviv Polytechnic National University
}

\begin{abstract}
Розглянуто сутність поняття «команда» та підкреслено його відмінність від звичайного колективу працівників, наведено технологію управління трудовими ресурсами у проекті з позиції фрункціонального підходу, висвітлено інсрормацію щодо управління персоналом проекту, яка подана у Керівництві до Зводу знань $з$ управління проектами, що є ключовим стандартом з управління проектами до сьогоднішнього дня. Представлено коротку характеристику Scrum методології та Scrum команди як прикладу сучасного організування команд проекту, наведено основні аспекти управління трудовими ресурсами в проектах та коротко розкрито їх сутність. Звернено увагу на віртуальні команди проекту, які стали основним видом під час пандемії, розкрито їх сильні та слабкі сторони, рекомендовано заходи щодо мінімізації проблем у віртуальних командах.
\end{abstract}

Ключові слова: команда, проект, управління, віртуальні команди, Scrum команди.

Рассмотрены сущность понятия «команда» и подчеркнуто его отличие от обычного коллектива работников, приведены технологию управления трудовыми ресурсами в проекте с позиции фрункционального подхода, освещены информацию по управлению персоналом проекта, представленная в Руководстве к Своду знаний по управлению проектами, является ключевым стандартом по управлению проектами до сегодняшнего дня. Представлены краткую характеристику Scrum методологии и Scrum команды как примера современного организации команд проекта, приведены основные аспекты управления трудовыми ресурсами в проектах и коротко раскрыто их сущность. Обращено внимание на виртуальные команды проекта, которые стали основным видом во время пандемии, раскрыто их сильные и слабые стороны, рекомендуется меры по минимизации проблем в виртуальных командах.

Ключевые слова: команда, проект, управление, виртуальные команды, Scrum команды.

The essence of the concept of "team" is considered and its difference from the usual team of employees is emphasized, namely in cohesion in order to achieve the set goals. The technology of human resources management in the project from the viewpoint of functional approach (planning of project work and the number of project team, their organization through the set and distribution of functional responsibilities, motivation through a system of material and moral incentives, control through evaluating the effectiveness of their project tasks and regulation detected deviations). The information on project personnel management, which is presented in the Guide to the Project Management Knowledge Base, which is a key standard for project management to date, is highlighted. A brief description of Scrum methodology as a kind of Agile methodology and Scrum team as an example of modern organization of project teams due to its flexibility, motivation, quick response to customer requirements, level of cohesion, change accounting, etc. The main aspects of human resource management in projects are presented, namely: change management (resistance), organizational management, adaptation management, knowledge management (development), conflict management, current motivation system based on Nudge methods - technology and a set of leadership skills and tools. Their essence and significance in 
the project team management are briefly revealed. Attention is paid to the virtual teams of the project, which became the main species during the pandemic. Based on the use of methods of generalization, observation and analysis, their strengths and weaknesses are revealed. Recommended measures to minimize problems in virtual teams, in particular using effective tools that operate in Scrum teams, namely: daily meetings, or increasing their number during the week, dividing the project into separate sprints, strengthening control over their implementation through retrospectives, openness in discussing problems, flexibility, etc. It is emphasized that the combination of classical approaches to personnel management and new trends in this area will ensure the effective functioning of project teams in the direction of achieving their goals.

Keywords: team, project, management, virtual teams, Scrum teams.

Постановка проблеми. В умовах сьогодення загальна концепція управління проектами набрала особливої популярності. Інструменти проектного менеджменту використовуються в різних галузях господарювання: не лише в будівельній інженерії та IT - сорері, але і в харчові промисловості, івент-менеджменті, консалтингу, зовнішньоекономічній діяльності тощо. Зокрема, при стратегічному плануванні рекомендується використовувати мережеві графіки, а при побудові організаційної структури управління скористатися допомогою побудованих робочих структур. Якщо ж говорити про інші сорери управління проектами як, наприклад, управління вартістю, ризиками чи якістю, то їх інструментарій є класичним для поточної фрункціональної діяльності підприємств різної фооми власності та галузі господарювання.

Однак, аналізуючи інструменти управління персоналом в проекті, слід зазначити, що дана сорера управління завжди потребує особливої уваги, оскільки людський ресурс - $є$ ключовим ресурсом в організації. I хоча, вже давно існуючі методи управління $€$ актуальними і досі, однак весь час вносяться корективи, оскільки змінюються не лише світові тенденції, але й сама особистість працівника, його вимоги, бажання, рівень його знань тощо.

Аналіз останніх досліджень. На сьогодні, ключовим стандартом 3 управління проектами і досі залишається Керівництво до Зводу знань з управління проектами (РМBOK: ), яке вже понад 30 років $€$ настільною книгою, універсальним інструктором для тих, хто прагне реалізовувати проекти та має бажання робити це ефективно. Вона була сорормована волонтерами Інституту управління проектами ще у 1983 році з метою звести основні знання з даної сфрери діяльності в єдину книгу - звід знань 3 управління проектами. Тому, аналізуючи дані, висвітлені у PMBOK [1], можна ствердно сказати, що питання управління людськими ресурсами тут розглядається досить різносторонньо.
Спершу, слід зазначити, що технологія правління командою проекту складається 3 реалізації загальних фрункцій менеджменту. Тому, розглядаючи загальну схему процесів управління трудовими ресурсами, висвітлено у Розділі 9 РМВОК, можна побачити наступний взаємозв'язок, а саме [1]:

1. Розроблення плану управління людськими ресурсами (планування).

2. Набір персоналу (організування).

3. Розвиток команди проекту (мотивування).

4. Визначення еорективності роботи команди проекту (контролювання) та забезпечення зворотного зв'язку та управління змінами (регулювання).

Однак, слід зауважити, що у РМВОК останній етап називається «управління командою проекту), однак, на нашу думку, ця назва не досить $€$ доречною, базуючись на фрункціональному підході, та розумінні трактування сутності менеджменту.

Основними пунктами у РМВОК щодо управління людськими ресурсами в проектах $€$ розгляд кожного з етапів вищенаведеного процесу за такими складовими як вхідні ресурси, методи та інструменти для досягнення поставленої цілі та вихідні результати, які заплановані до отримання. У ньому акцентовано увагу на ролі лідерства, мотивації, навчанні, розвитку, міжособистісних відносинах, управлінні змінами, особливостях веденні перемовин при наймі персоналу, та фракторах впливу на поведінку людей в командах, рівні їх співпраці тощо [1].

Останніми тенденціями в сорері управління персоналу в проектах $€$ створення Scrum команд. Про них не йдеться безпосередньо у РМВОК, однак ключові основи є закладені. Scrum - це методологія, яка $\epsilon$ складовою Agile менеджменту, що базується на концепції Менеджменту 3.0, відповідає усім сучасним вимогам управління та загальним уявленням про риси працівника у XXI ст. Scrum команди не підходять усім проектам за своєю технологією, однак вони є привабливими і ефективними через свою гнучкість, мотивованість 
членів команди проекту, рівень згуртованості, довіри, співпраці тощо. Scrum - методологія створює саме те середовище, яке сьогодні відповідає запитам працівників та потребам ринку, оскільки забезпечує високий результат у виконанні поставлених цілей за проектом [2; 4].

Незважаючи на популярність проектного менеджменту та використання його інструментарію в поточній діяльності, можна відмітити, що при управління персоналом і надалі користуються звичними старими методами, керівники важко адаптуються до потреб сьогодення і інновацій в даній сорері тощо, що залишається невирішеною частиною досліджуваного питання.

Формулювання цілей статті. Узагальнити існуючі підходи до управління персоналом в проектах. Виокремити основні ключові напрямки управління командою проекту. Зробити акцент на віртуальних командах, які формуються за вимогою сьогодення. Вказати на їх переваги та недоліки та запропонувати шляхи мінімізації їх проблем.

Виклад основного матеріалу дослідження. Команда, як відомо, - це група людей від двох і більше, які працюють для досягнення єдиних цілей. Для реалізації проекту дуже вагомим $\epsilon$ те, щоб персонал був саме командою, а не просто сукупністю людей, які свідомо або спонтанно координуються. Ïх не можна назвати «командою» [1].

В першу чергу, на фрормування команди саме як згуртованого колективу впливає керівник проекту, або можна сказати майстер, як це запропоновано у Scrum методології. Саме він повинен використовувати весь набір лідерських якостей та інструментів, щоб забезпечити задоволення основних потреб працівників (в основному вторинного характеру), мотивувати їх до виконання поставлених цілей, задавати орієнтир, бути прикладом, залагоджувати консрлікти, нівелювати опір тощо.

Велике значення в команді відіграє довіра. Звичайно, вона також залежатиме від керівника проекту, від його вміння організовувати колектив. Однак, окрім самого лідерського статусу керівника, було б добре також сорормувати і оголосити основні принципи роботи колективу та дотримуватися їх за будь-яких умов, не дозволяючи порушувати нікому основні правила. Керівник проекту як лідер повинен задати основний орієнтир, визначити критерії стосунків між членами своєї команди.

Сьогодні, як відомо, вторинні потреби працівників відіграють важливу роль в їх моти- ваційному арсеналі, тому керівництво проекту повинно ретельно визначати, які саме потреби прагне задовольнити член команди проекту і надати йому таку можливість. Особливе місце в цьому питання відіграє управління знаннями, так як підвищення кваліфікації та компетентності сприяє зростанню рівня самоповаги, забезпечує просування кар'єрою, надає важелі влади тощо. Як результат задоволення, прагнення працювати і досягати цільових показників за проектом.

Управління командою проектом включає в себе різні напрямки або аспекти, які слід враховувати для підтримання саме духу «команди» проекту: тобто єдності, згуртованості, довіри, злагодженості в роботі тощо.

Використовуючи різних мотиваційний інструментарій (матеріальні та нематеріальні стимулі) з метою заохочення членів команди до виконання поставлених завдань, паралельно можна також скористатися методами Nudge - технології (підштовхування), які б спрямовували працівників триматися певних вимог, зокрема встановити на персональні комп'ютери нагадування щодо проведення міні нарад, розвісити в приміщеннях пам'ятки про цілі команди, її принципи тощо [3].

Загалом, ключові напрямками управління трудовими ресурсами в проектах наведені на рис. 1.

На сам процес ефрективного управління персоналом проекту впливає наявний розгорнутий план 3 управління трудовими ресурсами, публічно представлений етичний кодекс, в якому би відображалися основні принципи поведінки між працівниками, між підрозділами та рівнями управління, зазначалися ключові постулати місії та бачення підприємства, його цінності; організаційна структура управління, розроблені посадові інструкції, діюча система мотивації, робочі структури проекту тощо. Слід враховувати і теорії організації при розробленні загальної концепції управління трудовими ресурсом в проектах. Вони допоможуть визначитися 3 поведінкою людей, їх міжособистісними стосунками тощо.

Особливою ознакою роботи сучасних команд в проектах $€$ дистанційність, коли члени команди навіть 3 однієї організації, не говорячи про осіб з різних підприємств, змушені контактувати між собою на відстані. Тому велике значення відводиться сьогодні саме віртуальним командам. Такі команди, звичайно, мають свої переваги, і про них навіть було описано у Зводі знань з управління про- 


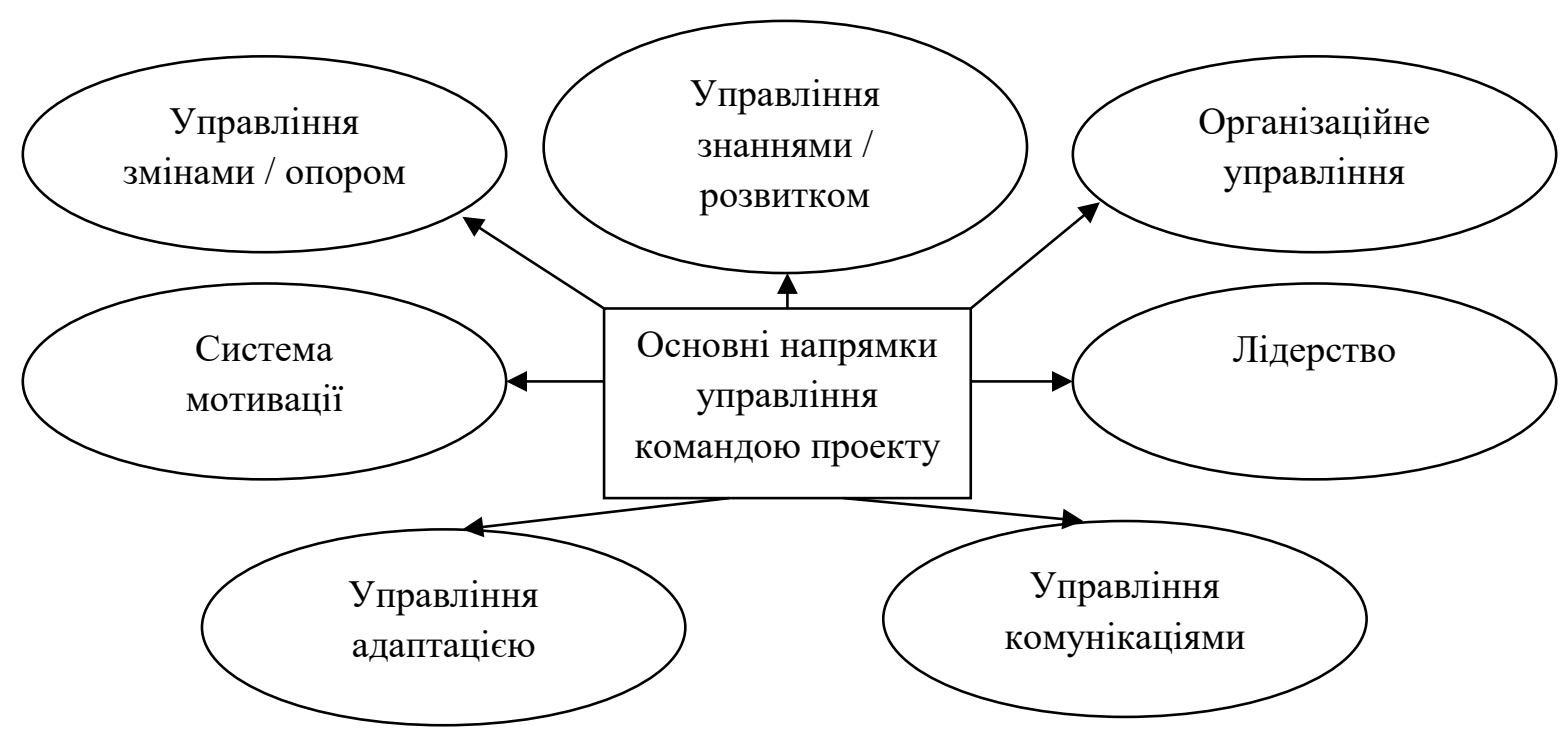

Рис. 1. Основні напрямки управління командою проекту

ектами. Однак, вони мають і певні труднощі в управлінні.

Перевагами віртуальним команд як в умовах пандемії, так і раніше $€$ [1]:

- можливість продовжувати роботу над проектом за будь-яких обставин (навіть в умовах карантину);

- можливість формувати команди проекту від особливостей їх біоритму;

- можливість залучати до проекту людей 3 інвалідністю, які за дистанційних умов, можуть в повній мірі брати участь в реалізації проекту;

- забезпеченість спілкуватися з експертами у відповідній сфрері знань навіть за умов їх далекого перебування від команди проекту.

Однак, сьогодні, створення віртуальних команд може бути вимушеною потребою. Тому, при управління ними, звичайно, без наявності досвіду, можуть виникати певні проблеми, а саме:

- труднощі 3 забезпечення адаптації працівника до колективу, за умови його первинної появи в ньому (первинна адаптація) або на основі, наприклад, міжкультурних розбіжностей.

- можливість упущення моменту появи конфрлікту на етапі, наприклад, його латентного перебігу, або опору через відсутність особистого контакту і можливості спостереження за роботою і стосунками між працівниками;

- мінімізація рівня ефективності від навчання 3 метою підвищення рівня кваліфрікації та компетентності через низьке сприйняття відео лекцій;

- посилення уваги зі сторони керівника проекту щодо розвитку команди проекту, іiї потреб з метою використання відповідних мотивуючих інструментів.

Звичайно, дані та інші проблеми з часом будуть вирішені, оскільки не у всіх керівників проекту є набутий досвід роботи дистанційно зі своїми командами. Однак, на сьогодні, процеси управління трудовими ресурсами саме у віртуальних командах потребують перегляду планів з адаптації, змін, управління конфрліктами, знаннями тощо. При цьому, також в нагоді стануть такі інструменти Scrumметодології як проведення щоденних нарад, поділ робіт на окремі блоки, регулярний контроль за виконання проміжних робіт у проекті за назвою ретроспектива, безпосередній поточний контакт з замовником проекту тощо.

Висновки. Керівництво зі зводу знань 3 управління проектами висвітлює, переважно, ключові аспекти щодо управління проектною командою. Однак, щоб досягнути бажаних результатів завдяки людським ресурсам, слід комплексно підходити до даного питання, а саме: варто вивчати останні тенденції в ссрері управління людьми, змінювати погляд керівництва щодо позиції менеджера і ставати лідером, забезпечувати довіру серед працівників, підштовхувати їх до поставлених цілей за допомогою Nudge - технологій. Керівникові або майстрові проекту варто усвідомлювати, що XXI століття сфрормувало зовсім іншого працівника, який прагне здобувати нові знання, профресійно зростати, отримувати задоволення від роботи, відчувати себе вільним та творчим. Відповідно і підходи до управління ним мають також дещо бути зміненими. 


\section{СПИСОК ВИКОРИСТАНИХ ДЖЕРЕЛ:}

1. Кестел Д., Даве В. Руководство к Своду знаний по управлению проектами (Руководство РМВОК). 5-е изд. Москва : Олимп-Бизнес, 2014. 586 с.

2. Scrum чи не Scrum - який підхід обрати? URL: https://worksection.com/ua/blog/scrum.html (дата звернення: 15.12.2020).

3. Передало Х.С., Огерчук Ю.В., Лібенко Ю.С. Поведінкова економіка та можливості застосування технік ії впливу в сучасних організаціях. Ефрективна економіка. 2019. № 12. DOI: 10.32702/2307-2105-2019.12.94 URL: http://www.economy.nayka.com.ua/?op=1\&z=7520 (дата звернення: 19.12.2020).

4. Апелло Ю. Agile - менеджмент: лидерство и управление командами. Москва : Альбина Паблишер, 2018. $534 \mathrm{c}$.

\section{REFERENCES:}

1. Kestel, D., Dave, V. (2014) Rukovodstvo k Svodu znanij po upravleniju proektami (Rukovodstvo PMBOK) [A Guide to the Project Management Body of Knowledge (PMBOK® Guide)], 5rd ed. Moskow: Olimp-Biznes.

2. "Scrum or not Scrum - which approach to choose" [Online]. Avaitable https://worksection.com/ua/blog/scrum.html (accessed 15 December 2020).

3. Peredalo, Kh.S., Oherchuk, Yu.V. and Libenko, Yu.S. (2019) "Behavioral economy and possibilities of its influence techniques application in modern organizations", Efektyvna ekonomika [Online], vol. 12. DOI: 10.32702/2307-2105-2019.12.94 Available at: http://www.economy.nayka.com.ua/?op=1\&z=7520 (accessed 19 December 2020).

4. Apello, Yu. (2018) Agile - menedzhment: liderstvo i upravlenie komandami [Agile - management: leadership and team management]. Moskow: Al'byna Pablysher. 